\title{
Refleksija ob pojmu romantika v glasbi
}

\section{Reflection on the Term Romanticism in Music}

Ključne besede: romantika, literarna veda, filozofija, estetika glasbe, zgodovina glasbe, recepcija

IZVLEČEK

Zdi se, da je raba pojma romantična glasba ali glasbena romantika $v$ vsakodnevni govorici že tako močno zakoreninjena in samoumevna, da se ponovno preverjanje pomena na videz kaže kot nepotrebno. Pretres nekaterih razprav sodobnega muzikološkega diskurza pa kaže povsem drugačno podobo: opredelitve pojma in pristopi pri tem so si tako zelo različni, da se zdi kakršna koli dokončna definicija pojma nemogoča. Toda iskanja bistva in legitimnih vzrokov za nastanek romantike v glasbi ne smemo omejiti zgolj na muzikološka dognanja, temveč zahteva poznavanje duhovnozgodovinske antropologije novoveškega človeka.
Keywords: romanticism, literary science, philosophy, aesthetics of music, history of music, reception

ABSTRACT

The use of the term romantic music, or musical romanticism, in everyday discourse is already so firmly rooted and self-evident that its renewed verification would seem, on the face of it, unnecessary. However, the debate in certain contemporary musicological discourse creates quite a different impression: the definitions of the term and the approaches to it are so diverse that any kind of final definition seems impossible. Nonetheless, the search for the essence and the legitimate causes for the emergence of romanticism in music cannot be limited simply to musicological findings, but rather demands an understanding of the spiritual-historical anthropology of modern man.

Že sam naslov pričujočega branja je iztočnica za nadaljnje razmišljanje in ne pot k enoznačni opredelitvi - k zapiranju že tako pogosto domnevno zaključenega vprašanja, ki ga poraja misel na pojem romantika. Zdi se, da vsak intenzivnejši pretres pojma predstavlja "fatamorgansko« približevanje 'resnici', torej se tik pred potrditvijo razblini. Sprašujem se, ali resnica sploh je samo ena in, ali je torej možna samo ena interpretacija romantike. Tudi Morse Peckham, znameniti raziskovalec teorije romantike, je podvomil v neovrgljivost pojma, vendar je prav v tem pesimistično naravnanem iskanju odgovora našel ključ s trditvijo, da je »konstrukcija romantične teorije inherentno nestabilna, in prav v tej nestabilnosti obstaja upanje za njeno dokazovanje«. ${ }^{1} \mathrm{~S}$ tem je hkrati potrdil mnenje Janka Kosa, da pomenski razvoj pojma, čeprav je dobil znanstven pomen in obseg že v drugi polovici

1 Morse Peckham. Romanticism and Ideology. Hanover, London: University Press of New England, 1995, 21. 
19. stol., še zmeraj ni dokončan. ${ }^{2}$ In če romantika - ne zgolj v literarnih, temveč tudi kulturnih in umetnostnozgodovinskih krogih - še dandanes predstavlja stopnjo v nedokončani evoluciji pojma, se prvotna zadrega pri poskusu končne definicije pojma nekoliko zrahlja in spodbudi k nadaljnjem poskusu razumevanja in razčlenjevanja le-tega. ${ }^{3}$

Še preden se posvetim naslovni misli, bi se na kratko ustavila pri razumevanju pojma romantika v literarni vedi; pa ne zgolj zato, ker naj bi te razlage bolj ali manj uspešno povzemala muzikološka literatura, temveč zato, ker se literarni zgodovinarji s to problematiko ukvarjajo veliko dlje in intenzivneje, kot pa (in to je tudi razumljivo) dosedanji muzikološki diskurz.

\section{1}

Leta 1968 je izšel zbornik Begriffsbestimmung der Romantik, ${ }^{4}$ ki je zajel dvaindvajset prispevkov vodilnih literarnih zgodovinarjev in filologov iz obdobja 1911-1968 in s tem tudi ključnih vprašanj definicije romantike (njene pojmovno zgodovinske trdnosti, v katero so zajete časovne, nacionalne in disciplinarne močno različne ravni in načini rabe besednega para romantika in romantično). Kljub temu pa predstavlja po mnenju sodobne literarne vede najtemeljitejši pretres literarnih poskusov (kako razložiti pojem in s tem »bistvo« romantike kot splošnoevropskega literarnega pojava) študija Concepts of Criticism ${ }^{5}$ Renéja Welleka. Ta je obveljala za izhodišče številnim sodobnim literarnim zgodovinarjem, ki so svoja stališča gradili, revidirali in preoblikovali ob njegovih ugotovitvah. ${ }^{6}$ Wellek je zavrgel vse tiste preozke definicije, ki niso mogle obveljati za vso romantiko, ter predlagal svojo, oprto na najsplošnejše, abstraktne poteze evropske romantične literature, ${ }^{7}$ s tem naj bi zajel najsplošnejše elemente romantičnega duhovnega in umetniško literarnega sveta, ne pa zgolj delnih aspektov posameznih nacionalnih romantik ali celo skupin le-teh. ${ }^{8} \mathrm{~V}$ poznejših razpravah je Wellek uvedel v pojem romantika nove razsežnosti prvotnega pojmovanja - bolj abstraktne, teoretičnofilozofske in spekulativne, ki so prav v kritičnem iskanju pomanjkljivosti tovrstnega razumevanja porodili nova dognanja.

Tako se z mnogimi Wellekovimi ugotovitvami strinja tudi Kos, ki svoj diskurz o romantiki gradi in poglablja prav na omenjenem delu, vendar se zaveda, da je potrebno bistvo romantike iskati predvsem v okviru tiste opredelitve, »ki lahko vse raznovrstne elemente zajame v enoto, s tem pa najde skupno osnovo različnim tipom evropske romantike«. ${ }^{9}$ Kos ugotavlja, da so v tej osnovi ne le literarnoestetski elementi romantičnega gibanja, ampak predvsem globlji, duhovnozgodovinski, metafizični, filozofsko duhovni in antropološki temelji, v katerih lahko vidimo predpostavke za nastajanje romantičnih literarnih tvorb. Tako Kos zanika vidik, ki skuša bistvo romantike definirati »v smislu antitetične tipologije«, tj. znotraj statično in shematično brezčasnega sistema nasprotnih umetnostnih teženj. Pravi, da bistvo romantike lahko dojamemo šele takrat, ko jo razumemo kot fazo v razvoju evropskega duhovnega in umetnostnega življenja,

\footnotetext{
Janko Kos. Literarni leksikon. Romantika. Ljubljana: Državna založba Slovenije, 1980, 26-27.

Pri tem imam v mislih predvsem pojem romantika v današnji muzikološki vedi.

Prim. Helmut Prang (ur.). Begriffsbestimmung der Romantik. Darmstadt: Wissenschaftliche Buchgesellschaft, 1968.

René Wellek. Concepts of Criticism. New Haven: Yale University Press, 1963.

Gl. Janko Kos, nav. delo, 27.

Te so: (1) vera v odločilno vlogo domišlije v pesništvu in umetniškem ustvarjanju, (2) nazor o posebnem pomenu in vlogi narave v doživljanju sveta, po katerem je narava organska celota in s tem podobna človeku, (3) poudarjanje pomena simbolov in mitov kot temeljnih sestavin literarnega ustvarjanja. Gl. Janko Kos, nav. delo, 30.

Ibid., 30.

Ibid., 33.
} 
kot stopnjo v procesu, ki zajema daljše obdobje evropske družbene, kulturne in umetnostne zgodovine, vse od konca srednjega veka do začetkov 19. stol. ${ }^{10}$ Zato mora duhovnozgodovinska razlaga romantike nujno temeljiti na analizi razvojnih tokov evropske kulture, filozofije in literature vse od renesanse naprej, torej mora upoštevati obsežen proces, ki bo kot tak lahko njen historično zakoniti položaj v razvoju evropskega duha od začetka novega veka naprej uveljavil kot legitimnega. Kos sicer navaja tri težnje, ${ }^{11}$ ki jih je Friedrich Schlegel razglasil za osrednje težnje časa in s katerimi je označil izvore romantičnega gibanja, kljub temu pa je prepričan, da je za razumevanje dejstva, da se je romantika formirala prav na prelomu stoletja, potrebno razumeti celovit proces, ki je od začetka novega veka v zaporednih stopnjah spreminjal podobo evropske kulture. Osrednji kazalec te je umevanje podobe človeka od 16. stol. naprej. Renesansa je prinesla obnovo človeka kot psihofizične celote, torej kot človeka, ki je postal najvišji izraz, potrditev in realizacija narave v 17. stol. A je Descartes to podobo zavrgel. Oče novoveške filozofije ji je postavil nasproti razlago človeka v smislu obnovljene dualistične antropologije: bistvo človeka je delil na psihično (duh) in fizično (telo), pri tem pa naj bi bila pravo bistvo človeka njegova subjektivna vsebina zavesti, fizična realnost pa naj bi jo zgolj dopolnjevala. ${ }^{12}$ Vendar Descartesov individuum še ni absolutno avtonomen, saj je v svojem obstoju še vedno zavezan zunanjemu metafizičnemu sistemu. To pomeni, da nova racionalistična metafizika, v središču katere stoji racionalno spoznavni Bog, (kot simbol za višji red stvari, ki presega vidno, minljivo in spremenljivo), še vedno omejuje subjektivnost človeka, saj je njegov obstoj še odvisen od obstoja Boga. Ta metafizični racionalizem je prevzela tudi umetnost 17. in 18. stoletja, ${ }^{13}$ ki je z metafizično transcendenco - objektivno in razumu dostopno - utemeljevala pojmovanje umetnostiv službi drugega (religioznega, moralnega). Korak bliže konceptu absolutno avtonomnega individuuma je naredil Immanuel Kant, ko je kategorično zavrgel tradicionalno metafiziko. Na njeno mesto je postavil subjekt, le-ta pa se je pri spoznavanju resničnosti lahko že zanašal le na kriterije svoje lastne, subjektivne zavesti. ${ }^{14}$ Kantova filozofska misel je postavila temelje nemški idealistični filozofiji, ki je lahko neposredno vplivala na romantiko prav zato, ker je »človekovo subjektivnost osvobodila okvirov metafizičnih bitnosti in jo postavila nanjo samo.$^{15}$

Kot ugotavlja Kos, se je šele z razpadom evropskega metafizičnega racionalizma lahko razcvetela romantika, katere subjektivnost je lahko postala absolutno avtonomna. Ker se je subjektivnost znašla zunaj tradicionalnih metafizičnih določil in brez transcendence nad sabo, je morala postati sama sebi edini izvor, zagotovilo in merilo, pa tudi ideal. In prav s tem so nastali vsi pogoji za izoblikovanje subjektivnosti, ki je postala vsebina, izhodišče in forma romantične umetnosti. ${ }^{16}$

Iz dosedanjih ugotovitev gre razbrati, da se je podoba človeka v romantiki uresničevala v absolutno avtonomnem individuumu, ki se je opiral zgolj na svojo (p)osebnost. Njena subjektivnost pa je postala samozadostna takrat, ko je bila že sama na sebi estetska. Zato

10 Ibid., 36.

11 Schlegel je v svojih fragmentih, objavljenih v Athenäumu, povezal tri težnje s tremi odločilnimi dogodki svojega časa: princip svobode s francosko revolucijo, princip subjektivnosti z nemško idealistično filozofijo in princip avtonomnosti estetskega $\mathrm{v}$ umetnosti z dosežki weimarske klasike.

12 Prim. René Descartes. Meditacije o prvi filozofiji, v kateri je dokazano bivanje božje in različnost človeške duše in telesa. Ljubljana: Slovenska matica, 1988, 17-24.

13 Janko Kos, nav. delo, 41.

14 Immanuel Kant. Kritika Čistog uma. Beograd: Kultura, 1985, 276-315.

15 Janko Kos, nav. delo, 41.

16 Ibid., 42. 
lahko razumemo, zakaj je bilo v romantiki estetsko glavni princip človeškega in umetniškega samovrednotenja. Z zanikanjem metafizičnega racionalizma se je zunanji ideal človeka prenesel v njegovo subjektivnost, skozi lastno čustvovanje in domišljijo pa je utelešal izkustvo absolutno avtonomne transcendence. Romantično pojmovanje subjektivnosti se je lahko zgodilo šele kot posledica nakazanega duhovnozgodovinskega procesa, utemeljenega s spreminjajočo se podobo človeka v evropski kulturi in filozofiji.

\section{2}

Kako se je ta plat romantične subjektivnosti izrazila v glasbeni umetnosti in kakšne posledice je imela za novo oz. drugačno pojmovanje glasbe okoli leta 1800, skuša odgovoriti teorija Lydie Goehr. V svojem prodornem delu The imaginary museum of musical works obravnava tudi premik, ki ga je romantična subjektivnost povzročila v novem pojmovanju glasbe. Zato ga označuje z romantično transcendenco in principom ločljivosti; njunega izvora ne gre iskati nikjer drugje kot v razumevanju procesa evropske novoveške kulture in filozofije. Torej, duhovnozgodovinska perspektiva je tista, s katero Goehrova argumentira romantično estetiko, s principom ločljivosti pa lahko razumemo prelom z miselnostjo metafizičnega racionalizma in vzpostavitev romantične transcendence. Goehrova pravi, da so vse do 18. stol. produktivne umetnosti razumeli funkcionalno, v službi socialnih, političnih in religioznih ciljev, s tem je bil tudi pomen glasbe v značilnih "zunajglasbenih « razsežnostih. ${ }^{17}$ Tako kot cilj ni bilo mišljeno zgolj izdelovanje (glasbenega) dela samo na sebi; to pomeni, da so glasbo dojemali predvsem kot 'izvedbo' in ne kot produktivno umetnost. ${ }^{18}$ Posledica principa ločljivosti in z njim nove romantične estetike je bila premik vrednosti in pomena - glasba nekoč v službi 'drugega' je prestopila v službo sebe same; s tem je zunajglasbena obveznost glasbe postala obveznost sebe same in razlikovanje med glasbenim in zunajglasbenim je lahko funkcioniralo le na besedni ravni in ne na ravni transcendence, saj je romantična estetika dovoljevala glasbi, da je pomenila »čisto glasbeno sebe in obenem vse drugo «. ${ }^{19}$

Goehrova se ne opira zgolj na estetske misli Kanta, Schellinga, Hegla in še nekaterih vodilnih mislecev klasičnega nemškega idealizma, temveč tudi na recepcijo glasbe umetnikov, literatov, glasbenih teoretikov in ne nazadnje samih glasbenikov na prelomu stoletja.

Posledica principa ločljivosti je bila - po Goehrovi - tudi emancipacija instrumentalne glasbe. Toda bolj kot v filozofski misli20 je bila ta dokumentirana v razpravah nemških literatov (F. Schlegel, W. H. Wackenroder, L. Tieck, E. T. A. Hoffmann idr.), ki so na prelomu stoletja instrumentalni glasbeni govorici priznali estetsko kategorijo poetičnost. Očitno je, da je impulz, s katerim se je vzpostavil njihov novi odnos do umetnosti, izhajal iz duhovnozgodovinskih predpostavk novoveške misli. Romantična estetika je svoj ideal utemeljevala v sami sebi oz. »bila je prepričana, da je največja lepota skrita v človeškem Duhu«. ${ }^{21}$ Estetska

Lydia Goehr se v tem segmentu sklicuje na filozofsko misel le v kontekstu "romantizacije lepih umetnosti« in ne konkretno glasbe same. Prim. Ibid., 157-159. Iz argumentacije Carla Dahlhausa je jasno vidno stališče filozofov 19. stol., ki naj bi na instrumentalno glasbo gledali z nezaupanjem. Gl. Carl Dahlhaus. Estetika glasbe. Ljubljana: Cankarjeva založba, 1986, 41-42.

21 Lydia Goehr, nav. delo, 160. 
vrednost je postala utelešena v sami umetnosti. (S tem pa razmerje do Boga in narave ni bilo zanikano, temveč je le dobilo nov pomen.) Tako se je, po besedah Goehrove, rodilo novo razmerje med umetniki in njihovimi umetniškimi deli - razmerje, ki je bilo nekoč podrejeno zunanjemu odnosu med umetniškim delom in tistim, kar je to posnemalo, je bilo sedaj izraženo kot notranji odnos izraza, natančneje, samoizraza, ki omejuje delo s svojim virom na podlagi katerega je nastalo. ${ }^{22}$ In prav ta izraz je od poznega 18. stol. postajal v glasbeni umetnosti izraza gibalo njene zgodovine, ki ga je vodilo načelo originalnosti. ${ }^{23}$

Princip ločljivosti se je manifestiral tako na načelni ravni nove romantične estetike kot v odnosu do konkretnega 'instrumentarija' umetniškega izražanja (denimo v odnosu do glasbene oblike in glasbenih inštrumentov). Goehrova pravi, da se je princip ločljivosti kazal tudi v romantičnih teorijah ustvarjanja in recepcije (estetska kontemplacija ni imela nobene odgovornosti v zvezi z religioznim, moralnim ali čustvenim 'spoštovanjem), prav tako pa je ločevanje estetske recepcije od vseh drugih vrst recepcije imelo neposreden vpliv na avtonomno naravo umetniškega dela. ${ }^{24}$

V prikazu nekaterih nastavkov teorije ločljivosti Lydie Goehr je moč razbrati vpliv in posledice romantično pojmovane subjektivnosti na sprejemanje in razumevanje glasbene umetnosti tako imenovanega romantičnega časa.

\section{3}

Dosedanje razmišljanje je v nekaterih obrisih skušalo poiskati bistvo in legitimne vzroke za nastanek (in opravičilo) romantike v glasbi. Ta ni zgolj (iz literature v glasbo prenesen) konstrukt zgodovine umetnosti, ki bi omogočal poenostavljeno in površno razlago fenomenologije glasbe, temveč posledica procesa duhovnozgodovinske antropologije novoveškega človeka. Čeprav je to dejstvo nedvomno skupno vsem umetnostim, je še vedno precej oddaljeno od izhodiščne tematike. Da bi se lahko približali razumevanju pojma romantika z glasbenozgodovinskega stališča, bodo v nadaljnji premislek vključene nekatere sodobnejše muzikološke razprave, ki se spopadajo z definicijo pojma.

Tako kot za literarni pomen pojma romantika velja tudi za njegov glasbeni ekvivalent, da so si ga glasbeni zgodovinarji in teoretiki zelo različno razlagali. 19. stoletje se tako v glasbeni zgodovini recepcije pojma izkaže za čas izjemno heterogenih razumevanj in interpretacij tega pojma, ki so si nemalokrat nasprotujoče in prav zato močno oddaljene od znanstveno objektivne oprijemljivosti. ${ }^{25}$ Muzikološki izsledki druge polovice 20. stol. so zato nedvomno tisto oporišče, v okviru katerih lahko iščemo vzpostavitev znanstvenega pomena pojma romantika v glasbi. V kolikšni meri pa ga je muzikološka veda uspešno definirala in pomensko zaobjela, bom skušala pokazati v nadaljevanju razmišljanja.

Verjetno bi za najodmevnejšo referenco evropske muzikološke misli lahko imeli članek Friedricha Blumeja iz leta $1963 .{ }^{26}$ Ta predstavlja odskočno desko vsem nadaljnjim tehtnejšim

22 Ibid., 162.

23 Gl. Carl Dahlhaus, Estetika glasbe. Ljubljana: Cankarjeva založba, 1986, 33-34.

24 Gl. Lydia Goehr, nav. delo, 171.

25 V tej zvezi postane več kot zgovorno delo Das schöne Unendliche Ulricha Taddayja, ki v osrednjem delu razprave ponuja prerez recepcije pojma v luči estetike, kritike in zgodovine 19. stol. Gl. Ulrich Tadday. Das schöne Unendliche. Stuttgart, Weimar: Verlag J. B. Metzler, 1999.

26 Prim. Friedrich Blume. 'Romantik'. V: Die Musik in Geschichte und Gegenwart. Allgemeine Enzyklopädie der Musikwissenschaft. Friedrich Blume (ur.) Zv. 11. Kassel: Bärenretier, 1963, 758-845. 
razpravam s tega področja bodisi kot osnova nadaljnjih razmišljanj bodisi kot »sprožilec«kritik. Blume se je dobro zavedal problematičnosti pojma v glasbi, saj je, kot ugotavlja, raba le-tega v zgodovini glasbe venomer ostajala nejasna. Tu ugotavlja, da je precej dvomljivo, kaj pojma romantika in »romantično« pravzaprav označujeta - stil, tehniko, oblikovni kanon, splošni umetniški koncept ali duhovno držo. ${ }^{27}$ Iz tega se smiselno poraja vprašanje razmejevanja obdobja, ki še zdaleč ni enotno. Blume razume romantiko in romantično na podlagi tega, kako so dojemali glasbo pisci in glasbeniki ob koncu 18. in začetku 19. stoletja. Prav zato ne preseneča njegova ugotovitev, da se je glasbena romantika začela hkrati z literarno romantiko in ne šele nekje med 1810. in 1820. (kot navajajo številni drugi glasbeni zgodovinarji). S tem da je Blume za začetek romantike v glasbi določil čas, ki ga zgodovinopisje pripisuje klasicizmu, je odprl vprašanje razmerja klasicizem - romantika. Zato v svoji razpravi ne želi postavljati ločnice med romantiko in prejšnjim obdobjem, saj se skozi recepcijo zgodovine izkaže, da nista v dialektičnem razmerju. ${ }^{28}$ Pri vprašanju romantike kot glasbenozgodovinskega obdobja je izpeljal trditev, da klasicizem in romantika (kot obdobji) sestavljata celoto, saj sta zgolj dva aspekta istega glasbenega pojava in istega zgodovinskega obdobja. ${ }^{29}$ Znotraj tega pojava in tega obdobja - vse do postopnega izteka v 20. stol. - pa je bila v ospredju enkrat bolj klasicistična, drugič bolj romantična smer. Ker sta ti dve zavezani osebnostim, smerem, modam in namenom, ju ni mogoče klasificirati. ${ }^{30}$ Blume se tudi sprašuje, koliko glasbe 19. stol. je v resnici romantične ter glede na to, da ni mogoče vseh skladateljev 19. stol. združiti v skupni imenovalec, definira romantično kot duhovno držo in ne kot stil.

Zdi se, da Blume skuša pojem romantika razložiti na temelju recepcijske zgodovine in nekaterih glasbenoestetskih spisov, toda pri tem je trčil na metodološko vrzel. Poskus sistematične (znanstvene) označitve pojma $\mathrm{z}$ argumenti, ki so sami po sebi subjektivne narave (večinoma gre za sodbe ljubiteljev glasbe - literarnih romantikov), ni razrešil Blumejevega vprašanja, kaj romantika sploh je. In čeprav jo označuje kot duhovno držo, pa nikjer ni pokazal jasne povezave med njo in glasbo samo. Njegovo razumevanje pojma pušča za seboj še veliko nerazrešenih vprašanj, vendar pa hkrati nakazuje številne problemske iztočnice, ki so v dotedanjem zgodovinopisju imele obrobno vlogo. Težko bi pritrdili, da se je z Blumejevo razpravo dvom o znanstvenem pomenu pojma romantika v glasbi razblinil, brez dvoma pa je opozoril na marsikatero nejasnost in postavil plodno osnovo nadaljnjim razmišljanjem.

Dvom, s katerim se Carl Dahlhaus loteva opredelitve pojma, je nakazan že v samem naslovu kratke razprave Glasba in romantika' (1980). Zavedal se je, da sta zvezi 'romantična glasba' in 'glasbena romantika' po eni strani klišejske narave, po drugi pa tako globoko zakoreninjeni, da ju skoraj ni mogoče izkoreniniti. ${ }^{22}$ In prav zaradi nedorečenosti ostajata zgolj "groba etiketa«, katere pomen v glasbi ostaja nejasen.

Dahlhausovo razmišljanje močno zaznamuje niz odprtih vprašanj, ki iz različnih zornih kotov načenjajo do takrat uveljavljeno umevanje pomena značilnih zvez pojmov.

27 Ibid., 785

28 Haydnovi sodobniki (kritiki) so skladateljevim delom pripisovali romantično glasbeno govorico.

29 Friedrich Blume, nav. delo, 802-806.

30 Ibid.

31 Naslov sugerira tako samostojnost obeh pojmov kot tudi njuno medsebojno prepletanje; obenem se distancira od dotedanjih pojmovnih zvez kot sta 'glasbena romantika' in 'romantična glasba'. Gl. Carl Dahlhaus. 'Musik und Romantik'. V: Die Musik des 19. Jahrhunderts. Wiesbaden: Athenaion, Laaber: Laaber, 1980, 13-21.

32 Ibid., 13. 
Avtor opozarja, da je poskus preciziranja te idejnozgodovinske kategorije, ki bi lahko postala uporabna za zgodovino, šele ko bi ustrezala zgodovinski resničnosti, vse prej kot preprosto dejanje. Združevanje različnih kategorij, kot sta denimo recepcija in produkcija, v en »krovni« pojem, se v Dahlhausovi razpravi znajde v številnih zadregah in paradoksih, ki pripeljejo prej v slepo ulico kot v tehtno definicijo glasbene romantike (npr. dejstvo, da gre nekatere Beethovnove simfonije v luči recepcije estetike razumeti kot »romantične«, nasprotuje klasicističnemu kompozicijskemu toposu, na katerem sloni logika skladateljevega glasbenega mišljenja). V svoji razpravi odpira še niz vprašanj, kot denimo: razmerje literarna in glasbena romantika, pojem politična (literarna) romantika in morebitna korelacija z glasbo, nasprotje klasicizem - romantika glede na odnos do preteklosti, »duha časa k kot recepcijska in ne produkcijska estetika ipd. Čeprav se sprva zdi, da razprava pretresa in postavlja pod vprašaj znanstveni pomen romantike v glasbi iz številnih kritičnih zornih kotov, pa Dahlhausov prispevek (nehote) sugerira ključ za nadaljnje razumevanje in raziskovanje te idejnozgodovinske kategorije. Svojo razpravo je sklenil z mislijo, da je treba zahtevo po tem, da bi »romantiko« zaobjeli v koncept, zavreči. Vendar je bolj kot dejstvo, da Dahlhaus postulira razpad znanstvenega pomena pojma, v ospredju njegov pristop pri sistematiziranju problematike. S tem da ugotavlja, da predpostavke nimajo skupne osnove (»jedra«), dvomi o možnosti opredelitve bistva romantike. ${ }^{33}$ Zato se izkaže za ključ razumevanja Dahlhausove razprave to: ne, ali lahko opredelimo bistvo romantike (v glasbi), temveč, zakaj ga ni moč povsem določiti v smislu enoznačnega pojma, kolektivnega imena. In prav v tem drugače preoblikovanem vprašanju gre iskati morebiten izhod ("upanje») za dokazovanje romantike (»inherentno nestabilne teorije«).

Da sta bila pojma »romantika» in "romantično« v glasbi nejasna še konec 80. let prejšnjega stoletja, potrjuje Peter Rummenhöller v svoji knjigi Romantik in der Musik ${ }^{34}$ (1989). Razprava, ki ne ostaja zgolj na ravni odprtih vprašanj in poskusov literarnospekulativnih definicij, temveč se s problematiko spopada na ravni konkretnih značilnosti, izpeljanih iz literarne romantike, in argumentiranih z glasbenimi deli, prinaša nov pristop pri razumevanju fenomena romantika v glasbi. Vsekakor uresničujeta pristop in metodologija dela izvirno konkretizacijo teoretskih nastavkov, s tem pa se izgubljeno 'verovanje' v določen stvaren obstoj romantike v glasbi ponovno vzpostavi. Rummenhöller se na začetku razprave najprej spopada z zamejevanjem glasbene romantike, pri tem pa izhaja iz razmerja literarna romantika - glasbena romantika. 140 let glasbene romantike ${ }^{35}$ se mu zdi nasproti 35 letom literarne romantike "pošastno" dolgo. Dihotomija postane še večja, ko ugotovi, da konec enega fenomena (literarne romantike) označuje začetek in polni čas delovanja drugega (glasbene romantike). Zato je izpeljal trditev, da romantika ni oznaka za obdobje, temveč je svetovni nazor, in od tod jo lahko vedno diagnosticiramo kot simptom dela ali skladatelja. To pomeni, da je skladatelj lahko le začasno romantik (Schumann), lahko kaže romantične težnje (kot Beethoven) ali pa je njegov profil popolnoma neromantičen in vendarle ima romantične poteze

\footnotetext{
Ibid., 21.

34 Peter Rummenhöller. Romantik in der Musik. Analysen, Portraits, Reflexionen. München: Deutscher Taschenbuch Verlag, 1989.

35 Pisec izhaja iz običajnih tolmačenj glasbenozgodovinskih razlag pojma.
} 
(Brahms). ${ }^{36}$ Zdi se, da takšno prepričanje izhaja deloma tudi iz zgodovine zvrsti, saj denimo Schumannova simfonična dela po Rummenhöllerjevih besedah predstavljajo revizijo glasbene romantike v korist novemu klasicizmu.

Čeprav se Rummenhöller strinja z mnogimi ugotovitvami Friedricha Blumeja, pa se težko sprijazni z njegovim razmejevanjem tega glasbenozgodovinskega obdobja. Pravi, da je treba, če želimo romantiki in romantičnemu povrniti smisel, njun pomen in rabo radikalno omejiti na določen čas. Postavlja ju na prvo polovico 19. stol., vendar z varovalko, da vse takratne glasbe ne gre označiti za romantično. ${ }^{37}$ Kot tri značilnosti romantike, romantičnega mišljenja, občutenja in umetniškega oblikovanja navaja: hrepenenje (usmerjeno v preteklost), trpljenje (kot negacijo sedanjosti) in utopijo (upanje v odrešitev). Za omenjene tri dimenzije je romantična umetnost razvila obilo motivov in simbolov, ${ }^{38} \mathrm{ki}$ pa niso prepoznavni zgolj v literarni umetnosti romantike, temveč tudi v glasbi sami. Uresničitev in dokazovanje motivov in simbolov v glasbeni umetnosti pa kot posledica potrjujeta njeno pripadnost romantiki oz. romantičnemu svetovnemu nazoru. Z izbiro skladateljskih imen, obravnavanih posamično (po poglavjih) in nekaterih bolj splošnih naslovov (K romantični harmoniji, Virtuoznost in romantika, Romantika in realizem ali utopija in resničnost), predstavlja Rummenhöller, kako se romantika reflektira v sami glasbi, v teksturi izbranih del. Zanj predstavlja romantika poudarek na novem in drugačnem, ki pa ne sloni zgolj na harmonsko-tonalnih odmikih in vzpostavitvi nove oz. rahljanju obstoječe glasbene zvrsti. Gre za niz detajlov - kompozicijskih tehničnih prijemov, ${ }^{39}$ ki uresničujejo romantično zavest, ponekod tudi ob pomoči romantičnih motivov in simbolov.

Takšno iskanje in dokazovanje romantike $\mathrm{v}$ glasbi se zdi veliko bolj prepričljivo kot vsa dotedanja razumevanja te idejnozgodovinske kategorije, saj ne ostaja zgolj na recepcijski ravni, temveč ponazarja uresničitev 'svetovnega nazora' v nizu konkretnih kompozicijskotehničnih prijemov, 'romantičnih' posegov v glasbeno teksturo. Torej Rummenhöller zelo nazorno in obenem previdno konkretizira literarni fenomen v glasbi, ne da bi ga zaobjel v koncept. Čeprav ponuja le nastavke za nadaljnje delo, predstavlja njegov poskus pionirsko dejanje v tovrstnih raziskavah.

Pristop v obravnavi pojma romantika pri Hansu Heinrichu Eggebrechtu (1991) se nekoliko razlikuje od dotedanjih razlag, saj nekakšen poskus definicije nadomešča zanimiva interpretacija obravnavane tematike. ${ }^{40}$ Tako kot mnogi njegovi predhodniki je mnenja, da definiranje pojma še zdaleč ni preprosto. Eggebrecht se je izognil kritiki uveljavljenih razlag romantike (v glasbi) in se osredotočil na besedni zvezi 'glasbena romantika' in 'romantična glasba'. Razume ju kot nasprotni kategoriji; prva pomeni način poetičnega mišljenja in pisanja o glasbi nasploh (»iterarna romantika glede na glasbo«), druga pa zadeva izključno novi način komponiranja (»komponirana romantika»), ki ga je po njegovem mnenju mogoče prvič razbrati v delih Franza Schuberta. Eggebrecht uvaja tako imenovani "model dveh svetov« ali princip romantičnega mišljenja o glasbi,

36 Peter Rummenhöller, nav. delo, 9

37 Kot pravo romantično generacijo skladateljev označi tiste »rojene okoli 1810«. Ibid., 10.

38 Med simbole našteje romantično ironijo, simbol ogledala, dvojčkov, maske in maškarade. Prim. ibid., 13-23.

39 Če jih naštejem le nekaj: kot romantično tendenco pri Beethovnu omeni med drugim zvočno barvo klavirja, ki je sicer še vedno v službi forme, vendar Schubertu, Chopinu in Schumannu jasno prepoznavna novost; na odlomkih Chopinovih skladb pokaže demonsko in iracionalno, romantično idejo neskončnosti, iracionaliziranje melodike in prizadevanje po zabrisanju meja, itd.

40 Gl. Hans Heinrich Eggebrecht. Musik im Abendland. Prozesse und Situationen vom Mittelalter bis zur Gegenwart. München, Zürich: Piper, 1991, 590-621. 
na podlagi tega pa potem razvija svojo razpravo. Model dveh svetov lahko poenostavljeno razlagamo takole: negacija resničnega sveta povzroča premik v svet umetnosti, ta pa fungira kot odrešitev od resničnega sveta. Čeprav prvi določa nastanek drugega, gre za dva povsem ločena svetova.

Ker naj bi se po Eggebrechtovem mnenju pojavnost modela najpopolneje zrcalila $\mathrm{V}$ Wackenroderjevih zapisih, izpeljuje iz njih pet značilnosti, ${ }^{41} \mathrm{ki}$ potem postanejo temeljni kazalci romantičnega mišljenja. Model dveh svetov aplicira še na ta imena 19. stol.: E. T. A. Hoffmanna, Schopenhauerja, Wagnerja, Hanslicka in Mahlerja. Pri vseh naštetih ga utemeljuje na osnovi njihovih spisov, refleksij in pričevanj, s tem pa potem potrjuje svojo tezo, da »romantike sprva ni mogoče najti v obliki konkretne glasbe «. ${ }^{42}$ Toda pri interpretaciji Mahlerja opazimo rabo modela tudi ob konkretnem glasbenem primeru. To dejstvo argumentira Eggebrecht z mislijo, da je glasbena romantika postala romantična glasba oz. da se je navzkrižje obeh svetov utelesilo v glasbi sami in ne najprej v besedni recepciji. ${ }^{43}$

Celotna razprava kaže pojmovanje romantike skozi prizmo zgodovine recepcije, ki pa se v sklepnem segmentu pojavi tudi kot način kompozicijskega mišljenja. Iz Eggebrechtovega zagovora gre razbrati, da je 'glasbena romantika' (= recepcija glasbe) učinkovala na 'romantično glasbo' (= produkcija). Vendar zagata nastane takrat, ko skušamo konkretizirati sam prenos poudarka z ene drže na drugo. Ni povsem jasno, na kakšen način se recepcija uresničuje v produkciji. In prav to pomanjkanje metodološkega orodja, ki naj bi predstavljajo most $\mathrm{v}$ transferju $\mathrm{z}$ ene kategorije na drugo, meče senco dvoma $\mathrm{v}$ prepričljivost Eggebrechtove razlage.

Preobrat v razumevanju in dokazovanju romantike v glasbi nedvomno prinaša delo Charlesa Rosena The Romantic Generation ${ }^{44}$ (1995). Razprava se je izognila problemskim vprašanjem in kritikam dotedanjih razlag romantike, prav tako ne išče vzporednic z literarno romantiko ali pa z recepcijo glasbene estetke, ne ukvarja se z zgodovinsko in teoretično določitvijo pojma, torej, kakor da ne bi bila obremenjena s tradicijo zgodovinskega spomina pričujočega fenomena. Njeno izhodišče predstavlja primerjalna kompozicijska praksa, to pa pomeni, da Rosen dokazuje romantiko na podlagi glasbene govorice izbranih skladateljskih del 19. stol. Analiza glasbenega gradiva je torej tista, v kateri fungira muzikološko pojmovanje romantike. Tako denimo ugotavlja, da je bila tonska barva pri Beethovnu še v službi forme, pri Schumannu pa je postala integralni del izhodiščnega koncepta. Kot pravi Rosen, so romantiki »trajno povečali vlogo zvoka v glasbenih kompozicijah « ${ }^{4}{ }^{4}$

Nasprotno od Rummenhöllerja, ki izhodišče raziskave utemeljuje v literarni teoriji romantike ter nekatere njene lastnosti prepoznava kot novosti v strukturi in fakturi glasbenih del, išče Rosen novosti v glasbeni govorici prve pol. 19. stol. glede na glasbeno tradicijo, tj. klasicistično zasnovana dela. Seveda pri tem ne zanemari vplivov literarne romantike, saj se, kot ugotavlja, ponekod kaže njen neposredni (Schumann), ponekod pa posredni

41 Te so: (1) najvišje mesto med umetnostmi ima glasba, (2) romantično mišljenje o glasbi se izraža kot poetična glasbena estetika, (3) romantično pisanje o glasbi ne ponuja estetike utemeljevanja, (4) mathesis postane podrejen emociji in (5) povzdigovanje glasbe na raven religije. Gl. ibid., 592-594.

42 Ibid., 590.

43 Ibid. 619-620.

44 Rokopis dela je nastal leta 1991, dve leti po Rummenhöllerjevi knjigi, kar pomeni, da bi težko govorili o nekakšnem medsebojnem raziskovalnem vplivu; Rosen pravzaprav nikjer ne navaja študij nemške muzikologije, ki govorijo o tej tematiki. Gl. Charles Rosen. The Romantic Generation. Cambridge (Massachusetts): Harvard University Press, 1995.

45 Ibid., 40. 
vpliv (Chopin). Vendar dejstvo, da literarna romantika ni imela odločilnega vpliva na nekatere romantične skladatelje, pomeni, da je ta fenomen v glasbi mogoče dokazati tudi brez primarne razlage literarnih romantičnih nastavkov. Izjemo predstavlja poglavje, ki govori o glasbenem fragmentu. Že Rummenhöller ugotavlja, da je bistvena značilnost romantičnega svetovnega nazora in deloma romantične estetike fragment. Kot pravi, se protislovje vsega romantičnega mišljenja - med neskončnostjo in sedanjostjo, med utopijo in resničnostjo - uresničuje v estetskem programu fragmenta, saj bi neskončnost snovi lahko bila sicer le zoženo predstavljena v konkretni, končni obliki. Prav zato se romantično oblikovanje izogiba eksaktnemu začetku in eksaktnemu koncu, s tem pa forma postane »razmejena« (»entgrenzt«). ${ }^{46}$ Pri romantični glasbi tako pogosto naletimo na ne-začetek in ne-konec. Čeprav Rummenhöller razmerja med literarnim in glasbenim fragmentom ni podkrepil tako temeljito in podrobno kot pozneje Rosen, se je njegova teza potrdila v natančni analizi Schumannovega klavirskega dela. ${ }^{47}$ Da je fragment kot romantična literarna oblika odločilno zaznamoval glasbeno umetnost 19. stol., dokazuje Rosen z razkrivanjem estetike fragmenta in prenosom te na druge umetnosti. Odločilni predstavnik omenjene estetike v glasbi je bil, kot je pokazal že Rummenhöller, prav Robert Schumann. Izjemne stilne spremembe glasbe poznega 18. stol. so na prelomu stoletja prinesle navdih pisateljem in pesnikom, katerih literarne oblike je zaznamovala precejšnja ekscentričnost. In prav ta dela so vplivala na glasbo generacije skladateljev, rojenih okrog leta $1810,{ }^{48} \mathrm{ki}$ so skušali ujeti izvirnost oblike in eksotičnega vzdušja sočasne literature in umetnosti. Če so se direktni literarni vplivi najbolj jasno manifestirali v umetnosti Schumanna, Berlioza in Liszta, pa to ne velja za Chopina. Kot pravi Rosen, pri Chopinu ne gre iskati narativnosti specifičnega literarnega dela, temveč novi ton, novo razpoloženje in nove strukture. Ob primeru Chopina predstavlja, da je pripadnost romantiki mogoče razlagati tudi ne upoštevaje dosežke in vplive literature. Ti so brez dvoma bolj relevantni za popolnejše razumevanje nekaterih glasbenih fenomenov in posameznih glasbenih poetik, vendar nikakor pa ne edini, s katerimi lahko razlagamo romantično glasbo.

Vsekakor je Rosenova razprava daleč od tega, da bi skušala zaobjeti romantiko v koncept. Z iskanjem specifičnih kompozicijskih lastnosti glasbenih del generacije skladateljev, rojenih okoli 1810, ki so bodisi značilne in prepoznavne v vseh njihovih poetikah (npr. zvočnost klavirja je postala primarna prvina v glasbeni kompoziciji, odsotnost melodije, predrugačenje baročnega kontrapunkta v prid novi slušni izkušnji, itn.) bodisi značilne za posamezna skladateljska imena, pa vendarle kaže, da idejnozgodovinska kategorija ne ostaja zgolj na ravni spekulativnega, temveč se lahko konkretizira v nizu značilnih kompozicijskih prijemov. Čeprav Rosen ni sistematiziral svojih odkritij v shematično pojmovanje glasbene romantike (kot sistem značilnosti in novosti na kompozicijskotehnično ravni), pa je pojmu zagotovil večjo verodostojnost in oprijemljivost $\mathrm{v}$ muzikološkem diskurzu.

46 Peter Rummenhöller, nav. delo, 18

47 Rummenhöller argumentira omenjeno tezo v analizi Schumannovega klavirskega dela »Warum? iz Phantasiestücken op. 12, No. 3. Gl. ibid. $135-139$.

48 Rummenhöller označi kot pravo romantično generacijo skladateljev tiste »rojene okoli 1810: Mendelssohn (1809), Schumann in Chopin (1810) in Liszt (1811). Pravi še, da je edino Liszt prestopil prag sredine stoletja in da kot skladatelj simfoničnih pesnitev ne pripada več romantiki. Ibid., 10. 
Iz prereza nekaterih sodobnejših muzikoloških razlag pojma romantika je mogoče razbrati, da so si opredelitve in pristopi pri razumevanju pojma različni. Kronologija omenjenih razprav izpričuje proces, ki idejnozgodovinsko kategorijo sprva razlaga $\mathrm{v}$ luči zgodovine recepcije, pozneje pa jo obravnava na ravni zgodovine kompozicije. Tako se kategoriji recepcija in produkcija izkažeta $\mathrm{v}$ zgodovini glasbe kot dva načina razumevanja pojma romantika. Vendar, da iz pojmovanj romantikov in njihovih sodobnikov ni mogoče izpeljati veljavne opredelitve pojma, ugotavlja že literarna veda. Zato ne preseneča, da so tiste muzikološke razprave, ki so romantiko utemeljevale zgolj na zgodovini recepcije, neredko trčile ob številne vrzeli. Nanje je prvi kritično opozoril Dahlhaus. Postavljati enačaj med recepcijo in kompozicijskotehničnim ustrojem del ne more zagotoviti veljavne opredelitve pojma; namreč ko z recepcijo skušamo razložiti kompozicijskotehnični ustroj del, je metodološka zagata neizogibna. Zato ne preseneča, da je bil v 80. letih pojem romantika v muzikologiji še vedno nejasen. Mnogi pisci so do takrat prav s sklicevanjem na njegovo 'nejasnost' zagovarjali svoje delne razlage, kaj naj bi ta v glasbi sploh pomenil. Dahlhaus se je bil pojmu romantika celo pripravljen odreči, saj se je ta v strogi znanosti pokazal za neuporabnega. S tem da je opozoril na problematiko klišejskih pojmovanj romantike, je pravzaprav odprl vrata morebitnim nadaljnjim razumevanjem tega.

Prenos poudarka z romantike kot kategorije recepcije na romantiko kot kompozicijsko kategorijo se nedvomno izkaže za uspešnejše razumevanje fenomena v glasbi. Čeprav Eggebrecht skuša povezati ti dve raziskovalni področji, pa iz njegove razlage ni povsem jasna povezava med obema. Bolj prepričljiv je bil na tem področju Rummenhöller, vendar gre njegov poskus razumeti predvsem kot nastavek za vse nadaljnje tovrstne raziskave. V nasprotju z Eggebrechtom utemeljuje Rummenhöller svoje pojmovanje romantike v glasbi na osnovi dognanj literarne teorije. Nekatere njene lastnosti prepoznava ob analizah samih kompozicij, s tem pa potrjuje obstoj (literarne) romantike v glasbi. Razprava sicer izpričuje izvirno metodologijo dela, vendar pa še zdaleč ne ponuja definicije pojma.

Rosenova razprava gradi pojmovanje romantike na analizi glasbenih del, s tem pa potrjuje dokončni prestop v raziskovanju in utemeljevanju fenomena k zgodovini kompozicije. Opozoriti je treba, da Rosen ne zanemarja literarne zgodovine in teorije ter glasbene recepcije. Toda uporablja ju le občasno in tudi takrat zgolj kot sredstvo dokazovanja izsledkov metode komparativne analize glasbenih del. Ob Dahlhausovem dvomu, da romantika v glasbi ni zgolj »tendenca k razkroju zvrsti«, ${ }^{49}$ ponuja Rosen niz konkretnih ugotovitev ter z njimi posplošeno in že naravnost klišejsko frazo dokončno ovrže.

Zanimivo je tudi, kako so se posamezni avtorji posvečali razmerju med besedama 'glasba' in 'romantika'; starejši raziskovalci se niso obremenjevali z besednima zvezama 'romantična glasba' ali 'glasbena romantika' kot avtorji nekaterih novejših raziskav. Besedni zvezi sta nekoč predstavljali tavtologijo, novejši muzikološki diskurz pa jima pomensko namenja veliko več pozornosti. Zato ni presenetljiva Dahlhausova izbira naslova 'Glasba in romantika', s katero namiguje, da gre za dva ločena fenomena, ki ju

49 Carl Dahlahus. 'Musik und Romantik'. V: Die Musik des 19. Jahrhunderts, 14. 
ne gre razumeti zgolj v smislu analogij. Rummenhöllerjev naslov razprave 'Romantika v glasbi' prav tako označuje dve področji (literarno in glasbeno), ki pa se v določenem segmentu lahko tudi pokrivata; in prav te značilnosti tako literature kot glasbe utemeljuje ob izbranih glasbenih primerih. Zanimivo je, da se Rosenov naslov 'Romantična generacija' povsem izogne problematičnemu razmerju besedne zveze glasba - romantika; tako ne le, da se svoje razprave loteva iz povsem drugačnega izhodišča, temveč hkrati posreduje neobremenjenost s tradicijo obstoječih muzikoloških (in literarnih) razlag pojma.

Prvi del prispevka je pokazal, da romantike ne gre razumeti zgolj kot literarno gibanje, temveč kot eno od faz v razvoju subjektivnosti novoveškega človeka v umetnosti, to ugotovitev pa je treba upoštevati tudi na ravni raziskovanja glasbene umetnosti kot takšne. »Bistva« romantike tako ne gre iskati v literarnem romantičnem gibanju, zgodovini recepcije glasbe in konkretnih glasbenih delih, temveč na podlagi duhovnozgodovinske analize razvojnih tokov evropske kulture, filozofije in literature. In prav ta duhovnozgodovinski razvoj je botroval vzpostavitvi romantično pojmovanje subjektivnosti, ki pa je v umetnostih vzpostavilo svoje principe delovanja in tudi oblikovanja literarnih/glasbenih del. Zavest, da je »bistvo« romantike zunaj konkretnih umetniških del in da ta s svojimi sredstvi izpričujejo zgolj realizacijo romantično pojmovane subjektivnosti, razjasni tudi problematiko razumevanja romantike v muzikološkem diskurzu. Šele potem, ko postane jasno na kakšnih principih deluje romantično pojmovana subjektivnost in kako se ti konkretizirajo v umetniških tvorbah, lahko bolj določno razlagamo, kaj je to romantika v glasbi in kako se v njej manifestira. In seveda, bolj kot v recepciji je ta zgovorna v sami produkciji, to pa pomeni, da postane primerjalna analitična metoda tisto sredstvo, ki zmore najobjektivneje pokazati, kako se romantično pojmovana subjektivnost kaže znotraj romantičnih glasbenih tvorb. Glede na dejstvo, da je romantična literatura imela izrazit vpliv na nekatere skladatelje prve polovice 19. stol., ne gre zanemariti ugotovitev literarne teorije, ki nedvomno pripomorejo k razumevanju podobe glasbe prve pol. 19. stol. Tudi recepcija glasbe lahko potrdi in razjasni marsikatero ugotovitev glasbenoanalitičnega pojmovanja romantike, vendar ne gre prezreti dejstva, da sta recepcija in produkcija dva dokaj samostojna glasbenozgodovinska fenomena. Čeprav se lahko v določenih segmentih pokrivata in celo pripeljeta do istih rezultatov, pa slonita na dveh s samostojno metodologijo izoblikovanih pristopih. Napačno bi ju bilo interpretirati v smislu analogij (da recepcija potrjuje zgodovinsko realnost kompozicije), ${ }^{50}$ kaj šele, da bi med njiju postavili enačaj.

Pričujoča kronologija izbranih muzikoloških razprav ni pokazala zgolj premika v obravnavi in pojmovanju romantike $\mathrm{v}$ glasbi z ravni recepcije na raven kompozicijske tehnike, temveč približevanje k objektivnejši in znanstveno bolj prepričljivi interpretaciji pojma. Namreč, v analizi glasbenih del utemeljeno pojmovanje romantike je prineslo veliko zgovornejše rezultate v prid zagovoru in rabi pojma znotraj muzikološkega diskurza. Zdi se, da se je nekoč zgolj spekulativna obravnava pojma v glasbi lahko končno konkretizirala v jasnih, prepoznavnih, določljivih kompozicijskotehničnih lastnostih del, ki so dobila pomen 'romantične glasbe', 'glasbene romantike' ali pa 'romantike v glasbi'.

Četudi je pot do znanstvene trdnosti pojma romantika (v glasbi) še vedno odprta, pa z novejšimi raziskavami postaja njegov pomen vedno bolj oprijemljiv. ${ }^{11}$

50 Npr. zgodovinska recepcija označuje Haydna za romantičnega skladatelja, torej to pomeni, da je Haydn romantik.

51 Tudi neovrgljiv, eksakten, enoznačen. 